Research Article

\title{
Difference of Vitamin D and Interleukin-6 Levels in Children with Steroid- Resistant, Steroid-Sensitive and Idiopathic Nephrotic Syndrome
}

\author{
Krisni Subandiyah ${ }^{1,4}$, Hervin Febrina Ghofar ${ }^{2,4}$, Loeki Enggar Fitri ${ }^{3}$ \\ ${ }^{1}$ Division of Nephrology, Department of Pediatric, Faculty of Medicine Brawijaya University, Malang 65145, \\ Indonesia \\ ${ }^{2}$ Department of Pediatric, Faculty of Medicine Brawijaya University, Malang 65145, Indonesia \\ ${ }^{3}$ Department of Clinical Microbiology, Faculty of Medicine Brawijaya University, Malang 65145, Indonesia \\ ${ }^{4}$ Department of Parasitology, Saiful Anwar General Hospital, Malang 65112, Indonesia
}

Article history:

Submission April 2018

Revised July 2018

Accepted September 2018

*Corresponding author:

E-mail: krisdika2002@gmail.com

\begin{abstract}
Idiopathic nephrotic syndrome (INS) is the most prevalent autoimmune glomerular disease in children and its pathogenesis is correlated with high level of interleukin 6 (IL-6) and low level of vitamin D. This study was aimed to investigate the difference of vitamin D and IL-6 level in steroid resistant nephrotic syndrome (SRNS), steroid sensitive (SSNS), and idiopathic nephrotic syndrome (INS). This research was designed as cross sectional involving 45 subjects which then divided into 3 groups as follows: SRNS, SSNS, and INS. A level of serum $25(\mathrm{OH}) \mathrm{D}$ was measured by Enzyme-linked Immuno Assay Method then categorized as sufficiency, insufficiency, and deficiency. Level of IL-6 serum was measured by ELISA method. Results showed that IL-6 level was significantly different among three groups, in which SRNS had the highest value (ANOVA, $p<0.05$ ). Further analysis demonstrated that IL-6 level correlated with steroid resistance (Spearman correlation test, $p=0.000, r=0.692)$. Vitamin $D$ status was significantly different among three groups (Chi square, $\mathrm{p}=0.03$ ) and associated with steroid resistance (Spearman correlation test, $\mathrm{p}=0.000, \mathrm{r}=0.568$ ). Moreover, IL-6 level associated with $25(\mathrm{OH}) \mathrm{D}$ level in SRNS group (Pearson correlation test, $\mathrm{p}=0.020, \mathrm{r}=$ 0.591 ) but not in the SSNS and INS group. We conclude that IL-6 levels were significantly higher in SRNS group as compared to other groups. Otherwise, vitamin D status were significantly lower in SRNS compared with other groups. An IL-6 level was negatively correlated with vitamin D status in patients with NS, specifically in SRNS group.
\end{abstract}

Keywords: Interleukin-6, nephrotic syndrome, vitamin D level

\section{Introduction}

Idiopathic nephrotic syndrome (INS) is the most prevalent autoimmune glomerular disease in children and the most common chronic disease [1, 2]. It is a group of symptoms characterized by severe proteinuria, hypoalbuminemia, hyperlipidemia, and edema [1]. The incidence of INS in children reached 2 up to 7 new cases every 100, 000 children and its prevalence is 12 up to 16 cases every 100.000 children. This disease is commonly found in younger children and the peak incidence is at 2 and 5 years old. In Indonesia, its incidence was 6 new cases per 100,000 children less than 14 years old annually and was dominated by male with ratio $2: 1$ [3]. Specifically, in Pediatric Ward of Saiful Anwar Hospital Malang, there were 101 INS patients hospitalized between January 2002 and December 2006 (accounted for 34\% of pediatric renal disease [4].

The underlying mechanism of nephrotic syndrome in children has not clearly understood yet, but principally related to immunological disorders [5]. Various cytokines such as interleukin (IL)-2, interferon (IFN)- $X$, IL-4, IL-12, IL-18, tumor ne-

\section{How to cite:}

Subandiyah K, Ghofar HF, Fitri LE (2019) Difference of Vitamin D and Interleukin-6 Levels in Children with SteroidResistant, Steroid-Sensitive and Idiopathic Nephrotic Syndrome. Journal of Tropical Life Science 9 (2): 179 - 187. doi: 10.11594/jtls.09.02.07 
crosis factor (TNF)- $\alpha$, IL-13, IL-17 and vascular endothelial growth factor (VEGF), might be involved in the pathogenesis of pediatric INS [6]. Wang in 2013 had been demonstrated that INS was characterized by immune-regulatory imbalance between helper $\mathrm{T}$ cell subtype 1 (Th1), Th2 and Th17 [7].

Interleukin-6 (IL-6) is a pleiotropic cytokine which has several functions such as stimulation of acute phase hepatic response and differentiation as well as the proliferation of macrophages, $T$ cells, and B cells [8]. IL-6 is closely associated with proteinuria and considered as glomerular permeability factor which initiate an immunological reaction in nephrotic syndrome. Otherwise, IL-6 is also correlated with steroid resistance [9-11].

Vitamin D 25(OH)D activity in glomerular mitochondria is elevated as $25(\mathrm{OH}) \mathrm{D}$ is converted into 1,25(OH)D. Renal disorders will lead to inhibition of 1,25(OH)D synthesis (active form of vitamin D3) which possess modulatory effect on immune response [12, 13]. Overall, immune-modulatory effects of 1,25(OH)D were based on several mechanisms: feedback response of paracrine gland to minimize inflammation or T-CD4 differentiation, improve the function of suppressor $\mathrm{T}$ cells, or both [14, 15, 16]. Previous study showed that vitamin D3 was safe and induce reduction of memory $\mathrm{B}$ cells, enhancement of $\mathrm{T}_{\text {reg }}$ and reduction of effector Th1 and Th17 cells [17]. Another study also revealed that the active form of vitamin D3 increase the level of IL-10 and Foxp3+ in TCD4 cell culture originated from human peripheral blood cells [18]. Besides its effect on inflammation, vitamin D3 also influence the regulation of glucocorticoid receptors. Furthermore, administration of the active form of vitamin D3 also enhances IL-4, IL-5, IL-13 expression of Th2 cells and IL-10 and TGF- $\beta$ of $\mathrm{T}_{\text {reg }}$ cells induced by dexamethasone in patients with steroid-resistant asthma [19]. This study was aimed to analyze the difference of IL-6 and vitamin D levels in children with steroid-resistant, steroid-sensitive, and newly diagnosed NS and also the correlation between IL6 and vitamin D.

\section{Material and Methods Study design}

This study was designed as cross-sectional study. Vitamin D [25(OH)D] serum and IL-6 lev- els were compared in three observed groups: steroid-resistant nephrotic syndrome (SRNS), steroidsensitive nephrotic syndrome (SSNS), and idiopathic nephrotic syndrome (INS). This research was approved by the Ethical Committee of Saiful Anwar Hospital, Malang.

\section{Subjects}

Research subjects were pediatric patients diagnosed as nephrotic syndrome and underwent outpatient care at Pediatric Nephrology Policlinic and inpatient care at Pediatric Ward Saiful Anwar Hospital Malang which meet the inclusion and exclusion criteria during the observational period. As many as $\mathbf{4 5}$ subjects were included in this study and then divided into 3 groups. Inclusion criteria for this study were as follows: categorized as steroid-sensitive, steroid-resistant, and idiopathic nephrotic syndrome, aged between 1-15 years old, parents allow his/her child to join this study after being given explanation (informed consent), have not received vitamin D treatment before the study. Exclusion criteria were as follows: secondary nephrotic syndrome; congenital/ infantile nephrotic syndrome; patients with other autoimmune diseases such as systemic lupus erythematosus (SLE), diabetes mellitus (DM); patients with allergic disease such as asthma, allergic rhinitis, atopic dermatitis, patients with severe infection or hepatic disorders. SSNS was defined as INS, which remitted after treated with full dose prednisone 2 $\mathrm{mg} / \mathrm{kgBW} /$ day for 4 weeks. In the other hand, SRNS was defined as INS, which did not improve after treated with full dose prednisone 2 $\mathrm{mg} / \mathrm{kgBW} /$ day for 4 weeks. Remission was defined as negative or trace proteinuria (proteinuria $<4 \mathrm{mg} / \mathrm{m}^{2} \mathrm{hpf} /$ hour) for 3 consecutive days in 1 week [1].

\section{Blood sample and serum preparation}

Blood samples were obtained from vein puncture then collected in a centrifuge tube. Blood samples were left clotted for 2 hours at room temperature or overnight at $4^{\circ} \mathrm{C}$ before being centrifuged. After clotting process, samples were centrifuged for 20 minutes at velocity $1000 \times$ g. Serum was obtained from each tube for measurement of vitamin $\mathrm{D}[25(\mathrm{OH}) \mathrm{D}]$ levels or stored in refrigerator at $-20^{\circ} \mathrm{C}$ or $-80^{\circ} \mathrm{C}$. 


\section{Measurements of vitamin D [25(OH)D] level}

Measurement of vitamin D levels was conducted as instructed by manufacturer (Alegria Human Vitamin D ELISA kit, catalogue number ORG 270). Briefly, $200 \mu \mathrm{L}$ pre-diluted serum was added into each well, then incubated for 2 hours at $25^{\circ} \mathrm{C}$. After washing procedure, $100 \mu \mathrm{L}$ enzyme conjugate was added then incubated for 30 minutes at room temperature. After washing procedure, $100 \mu \mathrm{L}$ substrate/ chromogen solution was added then incubated for 15 minutes at room temperature without shaking and should be protected from direct sunlight. Finally, $100 \mu \mathrm{L}$ stop solution was added into each well. Absorbance of blue color intensity was measured at wavelength 650 nm spectrophotometrically. Vitamin D then categorized as sufficiency (25(OH)D serum level $>20$ ng/mL), insufficiency (25(OH)D serum level 10 $20 \mathrm{ng} / \mathrm{mL})$, and deficiency (25(OH)D serum level $<10 \mathrm{ng} / \mathrm{mL}$ ) [20].

\section{Measurement of interleukin 6 level}

Reagent was prepared as instructed by manufacturer (RayBio®, catalogue number ELH-IL6). Firstly, $50 \mu \mathrm{L}$ assay diluents were added into each well. Secondly, $200 \mu \mathrm{L}$ standard or serum was added then covered and incubated for 3 hours at room temperature. After washing procedure (repeated for 3 times using $400 \mu \mathrm{L}$ washing buffer), $200 \mu \mathrm{L}$ IL-6 conjugate was added into each well, covered and incubated for 2.5 hours at room temperature. After washing procedure, $50 \mu \mathrm{L}$ substrate was added, then covered and incubated for 1 hour at room temperature. Finally, $50 \mu \mathrm{L}$ stop solution was added. Optical density (OD) was measured by using a microplate reader (Biorad 520 at wavelength $450 \mathrm{~nm}$ ).

\section{Statistical analysis}

Before analysis, data were tested for its distribution (normality) and homogeneity to qualify compatibility for parametric test. The differences of IL-6 level among 3 observed groups was determined by One Way ANOVA. The differences of vitamin $\mathrm{D}$ status was determined by Chi square test. Correlation of IL-6 level or vitamin D status with NS type was determined by Pearson correlation test or Spearman as its alternative data were analyzed with confidence interval 95\% using software SPSS for Windows version 24.0.

\section{Results and Discussion \\ Baseline characteristics}

This study involved children diagnosed with nephrotic syndrome and underwent outpatient care at Nephrology Policlinic and inpatient care at Pediatric Ward, Saiful Anwar Hospital during January-December 2016. As much as 45 subjects divided into 3 groups as follows: SSNS, SRNS, and newly diagnosed NS. Characteristics of subjects based on their groups were described in Table 1.

Median of age of SRNS, SSNS, and INS were 108 months, 138 months, and 72 months, respectively. Male was more frequently found compared with female (27 male and 18 female). Good nutritional status was commonly found in all groups. Furthermore, based on sex and nutritional status, there were no significant differences among three groups (Chi square test, $\mathrm{x}^{2} ; \mathrm{p}>0.05$ ).

\section{Interleukin 6 levels}

The highest IL-6 level was found in SRNS group (19.76 $\pm 10.04 \mathrm{ng} / \mathrm{mL})$ followed by INS $(5.07 \pm 3.54 \mathrm{ng} / \mathrm{mL})$ and SSNS (4.41 \pm 1.93 $\mathrm{ng} / \mathrm{mL}$ ) (Figure 1). Further analysis showed that there were significant IL-6 level differences among all groups (ANOVA; $\mathrm{p}=0.00$ ). Interestingly, IL-6 level correlated with SRNS (Spearman correlation test, $r=0.692, p=0.000$ ).

IL-6 level in SRNS was obviously higher as compared to other groups. Another study showed that IL-6 level before steroid treatment was not significantly different between steroid resistant and steroid sensitive NS group [21]. IL-6 and IL10 levels before treatment were higher in SRNS compared with SSNS [21]. Previous study also showed that IL-1, IL-6, IL-8 and TNF- levels were higher in nephrotic phase as compared to remission phase in pediatric INS [22]. The higher level of IL-1, IL-6, IL-8 and TNF- in nephrotic phase was associated with duration of steroid treatment until early remission [22]. Other cytokines such as IL-4 and IL-5 were also found higher in nephrotic phase, then step down in remission phase. The higher level of IL-4 and IL-5 in nephrotic phase was associated with duration of steroid treatment until early remission [23]. In accordance with those results, despite of unspecific time sampling (nephrotic vs remission phase), our study also showed significant correlation between IL-6 level enhancement and SRNS occurrence. 
Table 1. Baseline characteristics of subjects

\begin{tabular}{|c|c|c|c|c|c|}
\hline \multicolumn{2}{|c|}{ Characteristics } & SRNS $(n=15)$ & SSNS $(n=15)$ & INS $(n=15)$ & $\mathrm{p}$ value \\
\hline Age (month) $)^{\mathrm{a}}$ & $\begin{array}{l}\text { Median (month) } \\
\text { (Min - Max) }\end{array}$ & $\begin{array}{c}108 \\
(36-180)\end{array}$ & $\begin{array}{c}138 \\
(60-167)\end{array}$ & $\begin{array}{c}72 \\
(36-168)\end{array}$ & \\
\hline \multirow{2}{*}{ Sex } & Male & $10(10 / 15)$ & $9(9 / 15)$ & $8(8 / 15)$ & \\
\hline & Female & $5(5 / 15)$ & $6(6 / 15)$ & $7(7 / 15)$ & \\
\hline \multirow{4}{*}{ Nutritional status } & Good nutrition & $10(10 / 15)$ & $12(12 / 15)$ & $12(12 / 15)$ & \\
\hline & Undernutrition & $3(3 / 15)$ & $3(3 / 15)$ & $3(3 / 15)$ & \\
\hline & Malnourished & - & - & - & \\
\hline & Obese & $2(2 / 15)$ & - & - & \\
\hline
\end{tabular}

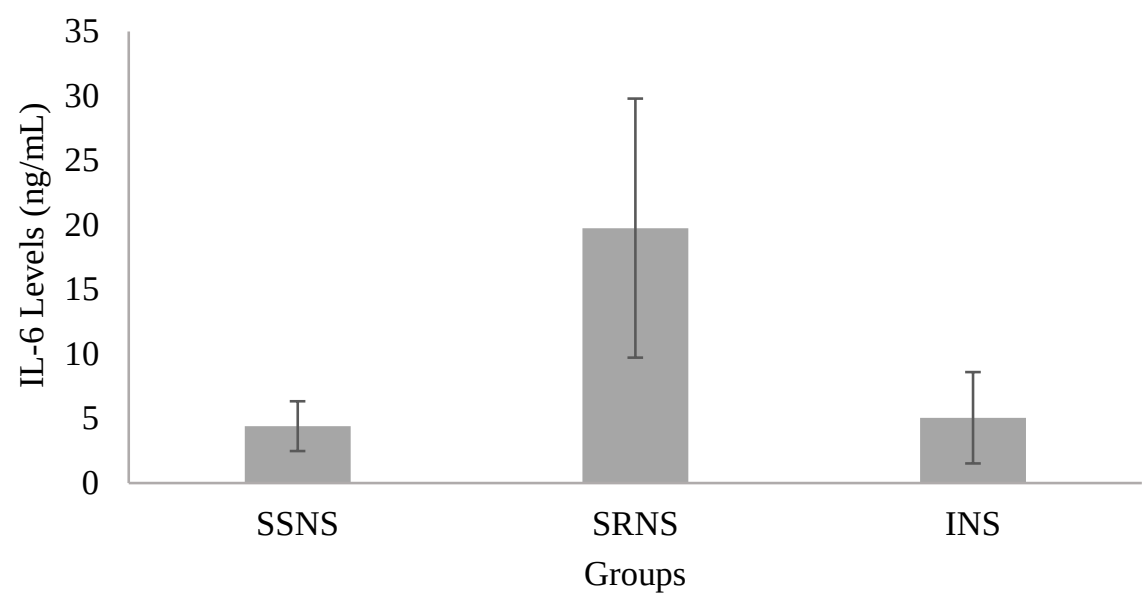

Figure 1. Mean of IL-6 Level in Each Group (SSNS, SRNS, and newly diagnosed NS). Data were presented as mean \pm SD

Interleukin-6 is proinflammatory cytokine which induces naive $\mathrm{T}$ cell differentiation into Th17 cells. Th17 cells are a subset of T-CD4+ cells, which could secrete proinflammatory cytokines such as IL-17, IL-17F, IL-6, and TNF- $\alpha$. Currently, the role of Th17 in various diseases had been known, including a steroid resistant nephrotic syndrome [24]. Flowcytometry analysis showed that Th17 population was increasing in peripheral blood samples from children with nephrotic syndrome. Besides that, enhancement of Th17 was also followed by increased of Th17-related cytokines such as IL-17, IL-23, and IL-6 [25].

The mechanism underlying IL-6-induced glomerular damage in steroid resistant nephrotic syndrome is not clearly understood. Wang and colleagues found that activation of Th17 and enhancement of IL-17 level trigger podocyte apoptosis activation through enhanced expression of Fas, caspase-8, and caspase 3 [7]. Furthermore, activation of Th17 also suppresses podocalyxin expression, thus cause a lack of negative ion at the glomerular basal membrane and sequentially induce proteinuria in nephrotic syndrome [7].

The differentiation process of Th17 was mediated by various signals which was activated by cytokine-receptor binding. First signal was mediated by binding of class II MHC (Major Histocompatibility Complex) and TCR (T-Cell Receptor). Second signal was mediated by binding of TGF- $\beta$ and its receptor which lead to formation of transcription factor Smads. Third signal was mediated by IL-6 binding to its receptor which will induce activation of transcription factor STAT3. Those signals synergistically induce the expression of Th17-differentiation-related genes [26].

Induction of IL- 6 and TGF- $\beta$ will lead to IL23 production by dendritic cells. IL-23 was considered as essential cytokine in stabilizing Th17 during differentiation and activation phase [27]. The role of IL-6 as proinflammatory cytokines had been further elucidated. Lal and Bromberg demonstrated that high level of IL-6 suppressed FoxP3 expression but induced RORyt expression. This situation will decrease the formation and function- 
Table 2. Vitamin D Status in SRNS, SSNS, and INS

\begin{tabular}{llll}
\hline $\begin{array}{l}\text { Vitamin D } \\
\text { Status }\end{array}$ & $\begin{array}{l}\text { SRNS } \\
(\mathrm{n}=15)\end{array}$ & $\begin{array}{l}\text { SSNS } \\
(\mathrm{n}=15)\end{array}$ & $\begin{array}{l}\text { INS } \\
(\mathrm{n}=15)\end{array}$ \\
\hline Sufficiency & - & $13.33 \%$ & $33.33 \%$ \\
Insufficiency & $13.33 \%$ & $46.67 \%$ & $46.67 \%$ \\
Deficiency & $86.66 \%$ & $40 \%$ & $20 \%)$ \\
\hline
\end{tabular}

alization of $\mathrm{T}_{\text {reg }}$ cells, thereby Th17 $: \mathrm{T}_{\text {reg ratio will }}$ increase. Several studies previously stated that as the IL-6 level was high, there would be suppressed stimulation of $\mathrm{T}_{\text {reg }}$ differentiation by TGF- $\beta 1$, thereby would be followed by Th17 predominant condition [28 - 31].

\section{Serum vitamin $D[25(\mathrm{OH}) \mathrm{D}]$ level}

This study categorizes serum 25(OH)D level into three groups as follows: deficiency, insufficiency, and sufficiency. Based on grouping system, as seen in Table 2, we found that 22 subjects were categorized as deficiency, 16 subjects were categorized as insufficiency, and 7 subjects were categorized as sufficiency. Moreover, vitamin D status was significantly different between three observed groups (Chi square test, $\mathrm{p}=0.03$ ). Further analysis demonstrated significant correlation between vitamin D status and NS types (Spearman correlation test, rs $=-0.568, \mathrm{p}=0.00$ ).

This study showed that vitamin D level in children with SRNS was higher compared with SSNS. Surveillance for children aged 0.5-12 years old conducted by South East Asian Nutrition Surveys (SEANUTS) had been reported that the prevalence of vitamin D insufficiency in Indonesia was the highest (more than 50\%) among 4 countries (Thailand, Vietnam, Malaysia, Indonesia) [32]. As the sunlight exposure (source of UV-B) abundantly available throughout the year, the possible etiologic factor of varying vitamin $D$ insufficiency in 4 tropical countries was the differences of vitamin D intake [32].

This study categorizes serum vitamin D [25(OH)D] into three groups as follows: deficiency (25(OH)D level $\leq 10 \mathrm{ng} / \mathrm{mL})$; insufficiency (25(OH)D level $10-20 \mathrm{ng} / \mathrm{mL}$ ); and sufficiency (25(OH)D $\geq 20 \mathrm{ng} / \mathrm{mL}$ ) [20]. Instead of NS grouping based on steroid resistance, vitamin $\mathrm{D}$ deficiency and insufficiency was commonly found in our study (accounted for $48.9 \%$ subjects and $35.6 \%$ subjects, respectively). However, this study did not document diet analysis regarding vitamin
D source such as milk, fish, egg and also sunlight exposure. This strategy is essential to control confounding factor of 25(OH)D level.

Furthermore, this study showed that 25(OH)D deficiency was commonly found in SRNS. Observational study conducted by the Department of Pediatric, Cipto Mangunkusumo Hospital reported that 22 of 26 NS subjects had low vitamin D level as follows: insufficiency in 10 subjects $(20-30$ $\mathrm{ng} / \mathrm{mL})$ and deficiency in 16 subjects $(<20$ $\mathrm{ng} / \mathrm{mL}$ ) (mean of $25(\mathrm{OH})$ D level was $20 \mathrm{ng} / \mathrm{mL}$ ) [33]. Vitamin D deficiency in pediatric NS could be caused by the enhanced glomerular filtration of vitamin $\mathrm{D}$ binding globulin (DBG). This condition would lead to decreased 25(OH)D concentration in serum [34]. Nielsen and colleagues reported that vitamin D insufficiency occurred in 93\% NS patients before steroid treatment; and this condition might be independently associated with steroid treatment [35]. Moreover, Nielsen and colleagues also showed that vitamin D level was positively correlated with albumin plasma level [35]. Therefore, hypoalbuminemia state in nephrotic syndrome would lead to decreased plasma vitamin $\mathrm{D}$ level caused by diminished its binding albumin. Other factors which influence plasma vitamin D level were age, sex, race, food intake, calcium level, as well as parathyroid hormone [36].

Our study showed that there were significant differences in vitamin D level among three observed groups. Interestingly, further analysis showed that vitamin D significantly correlated with nephrotic syndrome type. Banerjee and colleagues reported that vitamin D level was significantly higher in remitted NS group compared with a relapse NS group [37]. The increased vitamin D level was considerably caused by inhibition of the inflammatory response by steroid treatment as vitamin D indirectly used for suppressing the activation and proliferation of various immune cells [37]. Specifically, 25(OH)D downregulated Th1 cytokines and upregulated Th2 cytokines [38].

Furthermore, this study also showed that IL-6 level was significantly correlated with vitamin D level in steroid-resistant NS group. Nonn and colleagues reported that vitamin D could decrease IL6 production through tolerogenic dendritic cell activation [39]. Decreased IL-6 production enhances TGF- $\beta 1$ production, thereby would shift $\mathrm{T}$ cell differentiation dominantly into $T_{\text {reg }}$ cells. Enhancement of $\mathrm{T}_{\text {reg }}$ population would decrease Th17: $\mathrm{T}_{\text {reg }}$ 


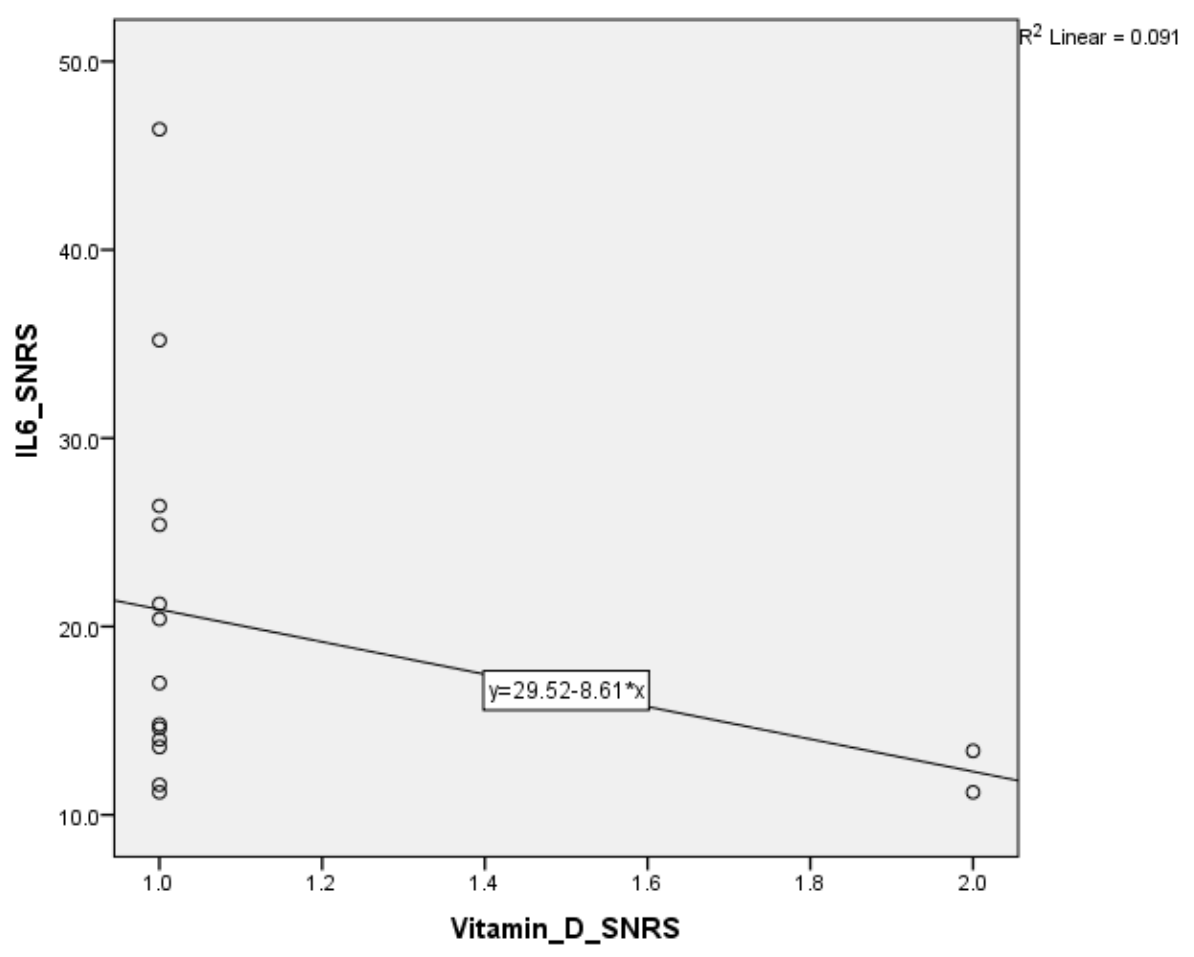

Figure 2. Correlation graph of IL-6 level and vitamin D in SRNS group

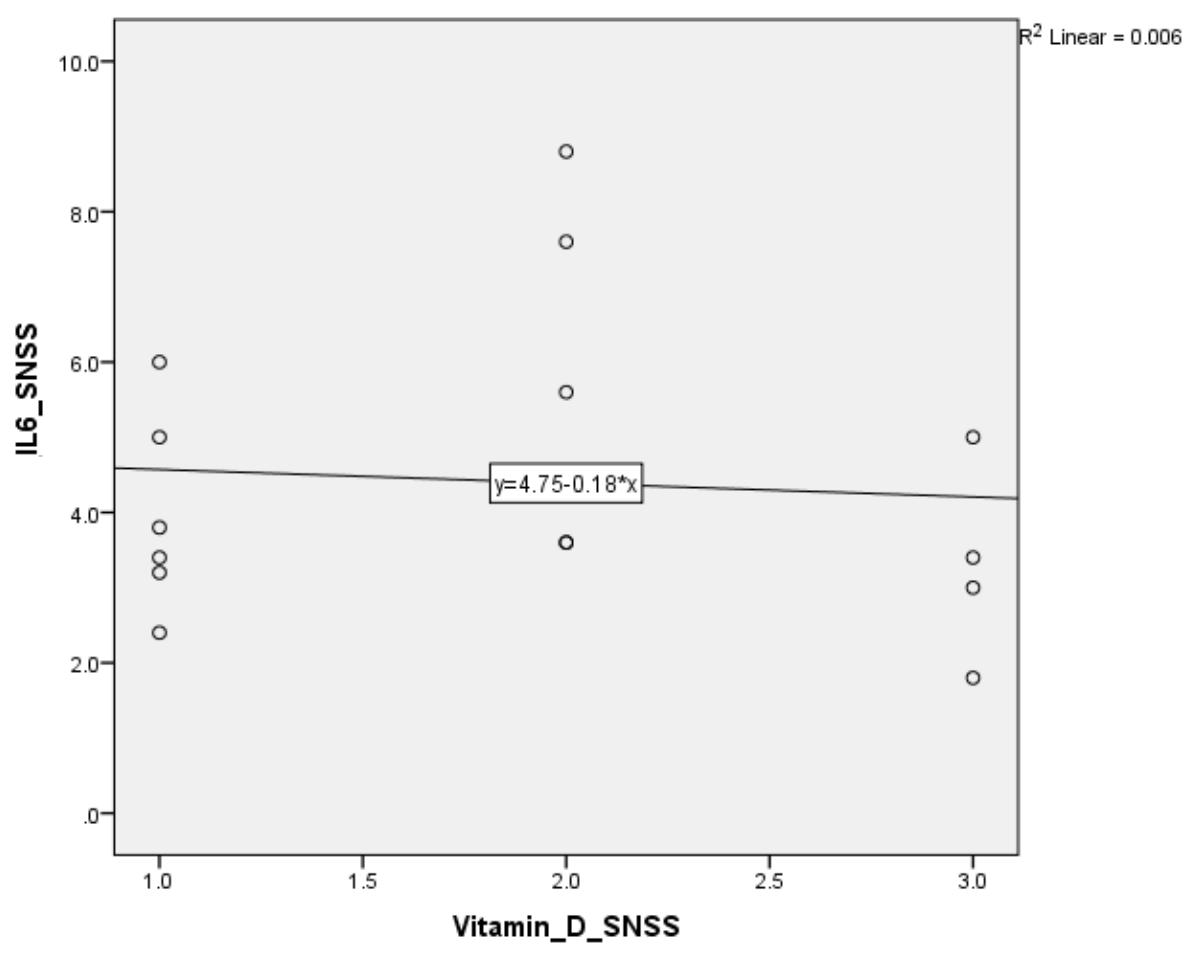

Figure 3. Correlation graph of IL-6 level and vitamin D in SSNS group 


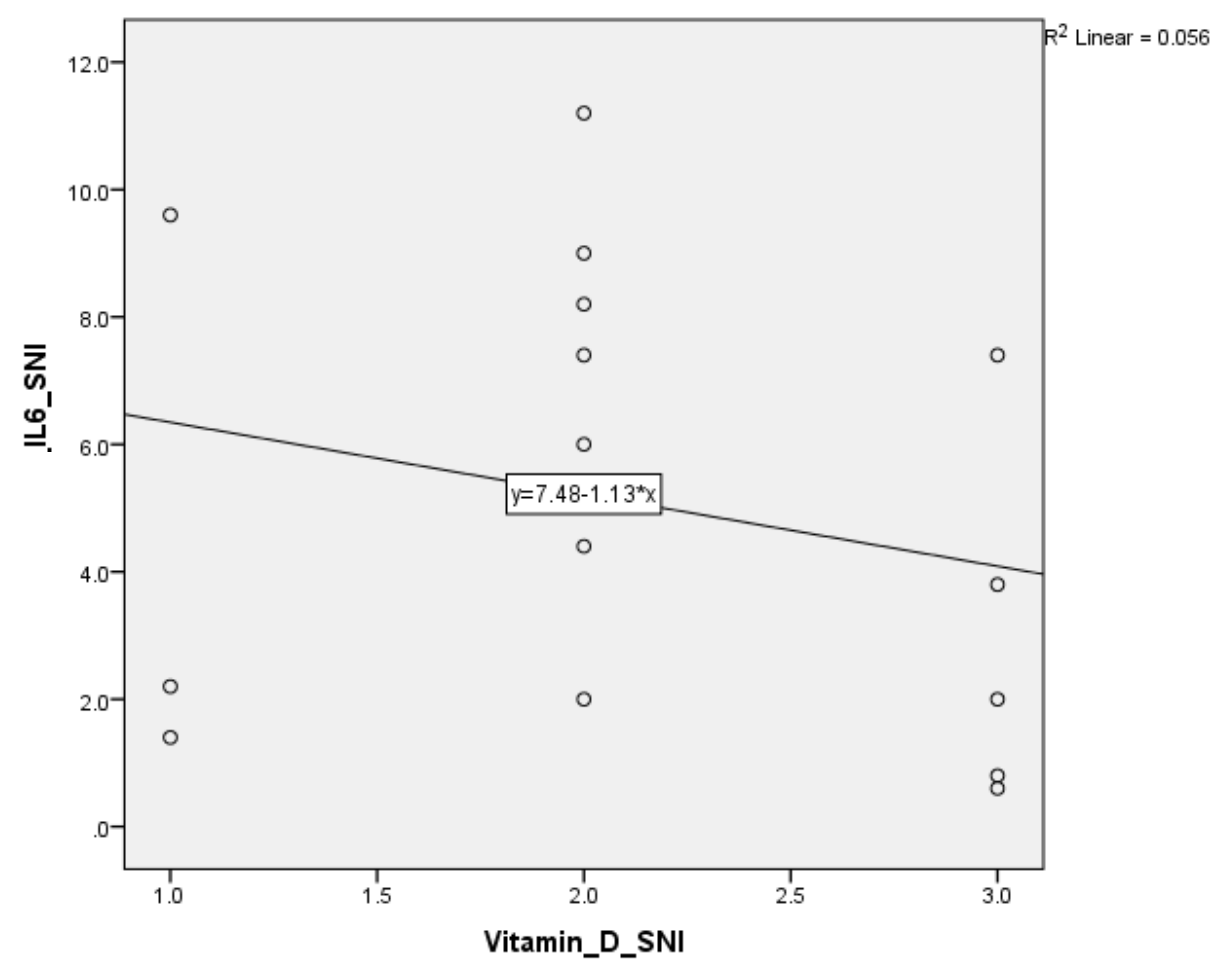

Figure 2. Correlation graph of IL-6 level and vitamin D in SRNS group

ratio and suppress Th17-related inflammation response. Finally, this condition would improve clinical condition of NS [30, 39, 40].

\section{Correlation of IL-6 level and vitamin D status}

Statistical analysis showed significant correlation between IL-6 level and vitamin D status in patients with NS ( $r s=0.481 ; \mathrm{p}=0.001$ ). Further analysis demonstrated that there was significant correlation between IL-6 level and vitamin D status only in SRNS group $(r=0.591, p=0.020)$, but not in SNSS group $(r=0.102, p=0.718)$ and newly diagnosed NS ( $r=0.328, p=0.232)$. Correlation graph of IL-6 level and vitamin D status in each group was shown in Figure 2, Figure 3, and Figure 4.

\section{Conclusion}

We conclude that IL-6 levels were significantly higher in SRNS group as compared to other groups. Otherwise, vitamin D status were significantly lower in SRNS compared with other groups. An IL-6 level was negatively correlated with vitamin D status in patients with NS, specifically in SRNS group.

\section{Acknowledgment}

The authors would like to thank West Nusa Tenggara General Hospital for providing research facilities during this study. The authors also thank Biomedika Hospital Mataram for providing funding (Annual Research Fund 2018-2019) to support this study.

\section{References}

1. Bagga A (2008) Management of steroid sensitive nephrotic: Revised guidelines. Indian Pediatrics 45 (3): 203 - 214.

2. Zhang J, Pippin JW, Krofft RD et al. (2013) Podocyte repopulation by renal progenitor cells following glucocorticoids treatment in experimental FSGS. Renal Physiology 304 (11): 1375 - 1389. doi: 10.1152/ajprenal.00020.2013.

3. UKK Nefrologi Ikatan Dokter Anak Indonesia (2008) Tatalaksana sindrom nefrotik idiopatik pada anak. Badan Penerbit Ikatan Dokter Anak Indonesia, Jakarta

4. Krisni (2007) Pola penyakit ginjal pada anak di RS Saiful Anwar Malang tahun 2002-2006 [oral presentation]. Pertemuan Ilmiah Tahunan Ilmu Kesehatan Anak Ikatan Dokter Anak Indonesia (PIT IKA-IDAI), Yogyakarta.

5. Hafez MA, Shimada M, Lee PY et al. (2009) Idiopathic nephrotic syndrome and atopy: Is there a common link? American Journal of Kidney Disease 54 (5): 945 - 953. doi: 10.1053/j.ajkd.2009.03.019. 
6. Kaneko K (2009) Pathogenesis in childhood idiopathic nephrotic syndrome: an update of patchwork. Current Pediatric Review 5 (1): 56 - 64. doi: 10.2174/157339609787587537.

7. Wang L, Li Q, Wang L et al. (2013) The role of Th17/IL-17 in the pathogenesis of primary nephrotic syndrome in children. Kidney \& Blood Pressure Reserach 37 (4-5): 332 - 345. doi: 10.1159/000350161.

8. Madani H, Bazaraa HM, Rady HI (2014) Association of cytokine genes polymorphisms and the response to corticosteroid therapy in children with idiopathic nephrotic syndrome: A pilot study in Egypt. International Research Journal of Medicine and Medical Sciences 2 (4): 84 - 90.

9. Chen WP, Lin CY (1994) Augmented expression of interleukin6 and interleukin-1 genes in the mesangium of IgM mesangial nephropathy. Nephron 68: 10 - 19. doi: 10.1159/000188217.

10. Yu YW, Ying ZQ (2005) Serum and urinary interleukin-6 levels in children with primary nephrotic syndrome. Chinese Journal of Contemporary Pediatrics 7 (6): 493 - 494.

11. Perreira Wde F, Brito-Melo GE, Guimaraes FT et al. (2014) The role of the immune system in idiopathic nephrotic syndrome: a review of clinical and experimental studies. Inflammation Research 63 (1): 1-12.

12. Ginanjar E, Sumariyono SS, Setiyohadi B (2007) Vitamin D and autoimmune disease. Acta Medica Indonesiana - The Indonesian Journal of Internal Medicine 39 (3): 133-141.

13. Takeda M, Yamashita T, Sasaki N et al. (2010) Oral administration of an active form of vitamin D3 (calcitriol) decreases atherosclerosis in mice by inducing regulatory $\mathrm{T}$ cells and immature dendritic cells with tolerogenic functions. Arteriosclerosis, Thrombosis, and Vascular Biology 30 (12): 2495 - 2503. doi: 10.1161/atvbaha.110.215459.

14. Baeke F, Takiishi T, Korf H et al. (2010) Vitamin D: Modulator of the immune system. Current Opinion in Pharmacology 10: 482 - 496. doi: 10.1016/j.coph.2010.04.001.

15. Hewison $M$ (2010) Vitamin $D$ and the immune system: new perspective on an old theme. Endocrinology and Metabolism Clinics of North America 39: 365 - 379. doi: 10.1016/j.ecl.2010.02.010.

16. White JH (2008) Vitamin D signaling, infectious diseases, and regulation of innate immunity. Infection and Immunity 76 (9): 3837 - 3843. doi: 10.1128/iai.00353-08.

17. Terrier B, Buzyn A, Hummel A et al. (2006) Serum monoclonal component and nephrotic syndrome--it is not always amyloidosis. Diagnosis: WM complicated by retroperitoneal and renal infiltration and associated with a minimal change disease. Nephrology Dialysis Transplantation 21 (11): 3327 - 3329. doi: 10.1093/ndt/gfl467.

18. Urry Z, Chambers EM, Xytrakis E et al. (2012) The role of $1 \alpha, 25$-dihydroxyvitamin D3 and cytokines in the promotion of distinct Foxp3+ and IL-10+CD4+ T cells. European Journal of Immunology 42 (10): 2697 - 2708. doi: 10.1002/eji.201242370.
19. Xytrakis E, Kusumakar S, Baswell S et al. (2006) Reversing the defective induction of IL-10-secreting regulatory T cells in glucocorticoid-resistant asthma patients. Journal of Clinical Investigation 116: 146 - 155. doi: 10.1172/jci21759.

20. Cho Y, Hyun SH, Kang GH, Cheong IH (2013) Prevalence of $25(\mathrm{OH})$ vitamin D insufficiency and deficiency in pediatric patients on chronic dialysis. Peritoneal Dialysis International 33 (4): 398 - 404. doi: 10.3747/pdi.2011.00246.

21. Salsano ME, Graziano L, Luongo I et al. (2007) Atopy in childhood idiopathic nephrotic syndrome. Acta Paediatrica Oslo Norwegia 96: $561 \quad$ - 566. doi: 10.1111/j.16512227.2007.00154.x.

22. Ece A, Colpan L, et al. (1999) Serum levels of interleukin IL$1 \beta$, sIL-2R, Il-6, IL-8, and TNF- $\alpha$ in children with idiopathic nephrotic syndrome. SDU Tip Fakultesi Dergisi 6 (2): 45 - 48.

23. Youn YS, Lim HH, Lee JH (2012) The clinical characteristics of steroid responsive nephrotic syndrome of children according to the serum immunoglobulin E levels and cytokines. Yonsei Medical Journal 53: 715 - 722 . doi: 10.3349/ymj.2012.53.4.715.

24. Iwakura $Y$, Ishigame $H$ (2006) The IL-23/IL-17 axis in inflammation. Journal of Clinical Investigation 116 (5): 1218 - 1222. doi: 10.1172/jci28508.

25. Shao XS, Yang XQ, Zhao XD et al. (2009) The prevalence of Th17 cells and FOXP3 regulate $\mathrm{T}$ cells $\left(\mathrm{T}_{\text {reg }}\right)$ in children with primary nephrotic syndrome. Pediatric Nephrology 24 (9): 1683 - 1690. doi: 10.1007/s00467-009-1194-x.

26. Pociask DA, Kolls JK (2010) Integral role of integrins in Th17 development. Journal of Clinical Investigation 120 (12): 4185 4187. doi: $10.1172 /$ jci45450.

27. Zhou TB, Lin N, Qin YH, Liu YG (2014) Distribution of pathological finding in the children with nephrotic syndrome from Guangxi. Saudi Journal of Kidney Disease and Transplantation 25: 684 - 688. doi: 10.4103/1319-2442.132240.

28. Lal G, Jonathan SB (2009) Epigenetic mechanisms of regulation on Foxp3 expression. Blood 114: 3727 - 3735. doi: 10.1182/blood-2009-05-219584.

29. Fujimoto M, Nakano M, Terabe F et al. (2011) The influence of excessive IL-6 production in vivo on the development and function of Foxp3+ regulatory T cells. Journal of Immunology 186: 32 - 40. doi: 10.4049/jimmunol.0903314.

30. Handono K, Hasanah DY, Mawarti H (2013) The associations among serum levels of vitamin D, TGF- $\beta /$ IL- 6 balance and Treg/Th17 balance in systemic lupus erythematosus patients in Indonesia. International Journal of Biochemistry and Biotechnology 2 (9): 490 - 496.

31. Tanaka T, Kishimoto T (2012) Targeting interleukin-6: all the way to treat autoimmune and inflammatory disease. International Journal of Biological Sciences 8 (9): 1227 - 1236. doi: 10.7150/ijbs.4666.

32. Poh BK, Rojroongwasinkul N, Nguyen BKL et al. (2016) 25- 
hydroxy-vitamin D demography and the risk of vitamin D insufficiency in the South East Asian Nutrition Surveys (SEANUTS). Asia Pacific Journal of Clinical Nutrition 25: 538-548. doi: 10.3390/nu10060759.

33. Septarini AD, Tambunan T, Amalia P (2012) Calcium and vitamin D supplementation in children with frequently relapsing and steroid-dependent nephrotic syndrome. The Indonesian Journal of Pediatrics and Perinatal Medicine 52 (1): 16 - 21. doi: 10.14238/pi53.1.2012.04.

34. Esmaeeili M, Azarfar A, Hoseinalizadeh S (2015) Calcium and vitamin D metabolism in pediatric nephrotic syndrome; an update on the existing literature. International Journal of Pediatric 3: $103-109$.

35. Nielsen CA, Jensen JEB, Cortes D (2015) Vitamin D status is insufficient in the majority of children at diagnosis of nephrotic syndrome. Danish Medical Journal 61: 1 - 5 .

36. Weng FL, Shults J, Herskovitz RM et al. (2005) Vitamin D insufficiency in steroid-sensitive nephrotic syndrome in remission. Pediatric Nephrology 20 (1): 56 - 63. doi: 10.1007/s00467-004-1694-7.
37. Banerjee S, Basu S, Sengupta J (2013) Vitamin D in nephrotic syndrome remission: A case-control study. Pediatric Nephrology 28: 1983 - 1989.

38. Jirapongsananuruk O, Melamed I, Leung DY (2000) Additive immunosuppressive effects of 1,25-dihydroxyvitamin D3 and corticosteroids on Th1, but not Th2, responses. Journal of Allergy and Clinical Immunology 106: 981 - 985. doi: 10.1067/mai.2000.110101.

39. Nonn L, Peng L, Feldman D, Peehl DM (2006) Cancer prevention by vitamin $\mathrm{D}$ protein kinase phosphatase 5 : Implication for prostate production in normal prostate cells via mitogen-activated inhibition of p38 by vitamin D reduces Interleukin-6. Cancer Research 66: 4515 - 4524. doi: 10.1158/0008-5472.can-053796.

40. Joshi S, Pantalena LC, Liu XK et al. (2011) 1,25-dihydroxyvitamin D3 ameliorates Th17 autoimmunity via transcriptional modulation of interleukin-17A. Molecular and Cellular Biology 31 (17): 3653 - 3669. doi: 10.1128/mcb.05020-11. 
This page is intentionally left blank. 